UDK 632.954:631.58

Pregledni rad-Review paper

\title{
Synergy between Crop Competition, Agronomic Practices and Herbicides for Effective Weed Control in Plant Production
}

\author{
Zvonko Pacanoski \\ Faculty for Agricultural Sciences and Food, Ss. Cyril and Methodius University, Skopje, R. N. \\ Macedonia \\ e-mail: zvonko_lav@yahoo.com; zvonkop@zf.ukim.edu.mk
}

\begin{abstract}
SUMMARY
Interaction of herbicide application with the manipulation of certain agronomic practices for crop competition, including sowing date and seeding rate, row and plant spacing, and application of fertilizers have the potential to reduce the abundance of agricultural weeds and optimize herbicide use. Sowing date and herbicide application play a significant role in determining growth, development and seed yield of many crops, as well as reducing weed density and weed biomass. Narrow row spacing can improve weed control because weeds are smaller and more easily controlled with herbicides than they are in wide row spacing. Furthermore, the more rapid crop canopy development of narrow row spacing reduces problems with late emerging weeds and may allow POST EM herbicides to be applied earlier in the season, therefore improving effectiveness and allowing reduced rates to control small weeds. Finally, adequate fertilization increases the vigour and competitiveness of the crop. By altering the time and method of fertilizing with herbicide application, competitive advantage can be shifted in favour of the crop.
\end{abstract}

Keywords: agronomic practices, herbicides, fertilizers, weeds.

\section{INTRODUCTION}

In many agricultural systems around the world, competition with weeds is one of the major factors limiting profitable crop production (Avery, 1997). In developed countries, despite the availability of high-tech solutions (e.g. selective herbicides, GM and HR crops), the share of crop yield loss to weeds does not seem to reduce significantly over time (Cousens and Mortimer, 1995). In developing countries, herbicides are rarely accessible at a reasonable cost, therefore forcing farmers to often rely on alternative methods of weed management. 
Weed management through physical and mechanical means often increases soil erosion rates, leading to deteriorating physical, chemical and biological properties of soil (Wall, 2007), reduced soil quality, i.e. soil structure, with consequences for water infiltration (Thierfelder and Wall, 2009), poor soil porosity, nutrient loss and low organic matter content (Kirschbaum, 1995), which leads to increased greenhouse gas emissions (Del Grosso et al., 2005). Furthermore, such weed management practices involve intensive labour and implement high costs, making them simultaneously more laborious, tiresome and expensive (Iqbal, 1994). On the other hand, reliance solely on chemical weed control involves excessive use of herbicides, resulting in pollution of the environment and inter- and intra-specific shifts (Hassan and Marwat, 2001), due to the development of more competitive herbicide-resistant biotypes within a plant population or a community, which are a threat for sustainable crop production (Shrestha et al., 2010; Chhokar et al., 2012).

Weed management programs should therefore not rely totally on either chemical or mechanical means, due to their respective potential risks and costs. One such strategy is the combination of cultural or ecological weed control with chemical weed control. Cultural weed control involves manipulation of the crop/weed environment so that the conditions become more favourable for crop plants than for weeds (Klein et al., 2006). Cooordinating herbicide applications with the manipulation of certain agronomic practices for crop competition such as sowing date, seeding rate, row and plant spacing, as well as application of fertilizers, have the potential to reduce the abundance of agricultural weeds and optimize herbicide use (Conley et al., 2001; Filizadeh et al., 2007; Erfanifar et al., 2008; Hamouz et al., 2014; Woźniak and Soroka 2015).

Sowing date and herbicide application play a significant role in determining growth, development and seed yield of many crops. Results show that different sowing date and herbicide weed control method have a significant effect on relative weed density, weed biomass, weed control efficiency, plant height, dry plant weight and seed yield of soybean (Akter et al., 2016), rice (Mubeen et al., 2014), wheat (Duary and Yaduraju, 2006) and pearl millet (Arslan et al., 2018).

Narrow row spacing can improve weed control because weeds are smaller and more easily controlled with herbicides than they are in wide row spacing. Furthermore, the more rapid crop canopy development of narrow row spacing reduces problems with late emerging weeds and may allow postemergence herbicides to be applied earlier in the season, therefore improving their effectiveness and allowing reduced rates to control small weeds (Hartzler et al., 1996). Closer row spacing of $15 \mathrm{~cm}$ with $50 \%$ higher seed rate and cross sowing showed a distinct advantage in reducing the weed population and dry weight (Chhokar et al., 2012). Prakash et al. (1986) found closer row spacing $(15 \mathrm{~cm})$ and reduced dose of herbicide to be effective in reducing weeds and increasing wheat grain yield.

Adequate fertilization increases the vigour and competitiveness of the crop. By altering the time and method of fertilizer and herbicide application, competitive advantage can be shifted in favour of the crop. The initial crop growth will be better if the fertilizer is made more available to the crop instead of weeds and, in the same time, the efficacy of herbicides 
is increased when it coincides with the application of the fertilizer (Sosnoskie et al., 2009). Synergism between herbicides and fertilizers in control of broadleaved weeds in wheat and barley were reported by Prishchepa (1999). Application of isoproturon at 1.5 or $1.0 \mathrm{~kg}$ a.i. ha1 , followed by a top dressing with $\mathrm{N}$ at $35 \mathrm{DAS}$, resulted in lowest accumulation of weeds dry matter, highest number of effective tillers per meter length, spikelet's spike, straw and grain yield ha-1 of wheat (Saini and Angiras, 1998).

Taking into consideration what has been said before, the objective of this report is to summarize the available information and bring together advantages of effective weed control through interaction between crop competition, agronomic practices and herbicides.

\section{SYNERGY BETWEEN HERBICIDES, SOWING DATE AND SEEDING RATE}

The use of herbicides to control weeds has facilitated the adoption of several important agronomic practices and has major impacts on all phases of crop production. Seeding date manipulation for weed control involves trying to increase the crop's competitive ability, compared to that of the weeds. The timing of weed emergence relative to the crop is the main factor to consider, since weeds that emerge before the crop compete more aggressively with the crop than those that emerge after the crop. Until the 1950s, delayed seeding in interaction with herbicides was the most effective way of controlling weeds in spring-sown crops. Early sowing, as is common today, was impossible because weeds would outcompete the crop. Spring cultivation, after weed emergence, removed weeds before crop planting, but delayed planting by approximately three weeks (Weller et al., 2014). Earlier planting, as now practiced, reflects the availability of hybrid seeds with a higher cold tolerance and decreased need for spring tillage, made possible by the use of herbicides (Warren, 1998). In the U.S. Midwest, corn planting occurs two weeks earlier today than it did in the late 1970s, and in the mid-southern part of the United States for the $50 \%$ of corn the planting date has moved earlier by about a month (from early May to early April) during the past 30 years (Kucharik, 2006). In northern Alberta, a six-year crop rotation including delayed seeding and POST EM herbicides in three years out of six resulted in a $87 \%$ decrease in Avena fatua populations, compared to a $4 \%$ decrease in a wheat-fallow rotation (Anonymous, 1968). In another Alberta study, allowing Avena fatua to grow to the two-leaf stage and then destroying it with either tillage or herbicides prior to seeding rapeseed resulted in good control, with little or no crop yield loss (Darwent and Smith, 1985). Waiting until Avena fatua was in the three- to four-leaf stage resulted in good control, but some yield loss. A Manitoba study on oat found that Avena fatua populations were reduced drastically by POST EM herbicides and delayed seeding from early to late May, without sacrificing crop yield (Schoofs et al., 2005). Gürsoy et al. (2014) found that late plantings of lentil (November 23), where cultivator and POST EM herbicides were used after rainfall, reduced weed density and dry weight biomass, and gave significantly more lentil seeds than early planting (October 19). 
Increased seeding rate and use of herbicides are two important components of integrated weed management program. Planting late-planted wheat at higher seeding rates improves yield and weed competitiveness of the crop. In many areas in Jordan high seeding wheat rates of $140 \mathrm{~kg} \mathrm{ha}^{-1}$, in interaction with herbicides, are used as a form of control of high competitive wild oats and broadleaved weeds (Munir et al., 2002). Findings of Marwat et al. (2011) revealed that integrating line wheat sowing with higher seed rate $\left(150 \mathrm{~kg} \mathrm{ha}^{-1}\right)$ and Buctril super suppressed weeds by more than $90 \%$. In investigation of Jhala et al. (2008) interaction effect of seed rates and weed management treatments revealed that treatment combinations $160 \mathrm{~kg}$ $\mathrm{ha}^{-1}$ and $180 \mathrm{~kg} \mathrm{ha}^{-1}$ with pendimethalin applied PRE EM recorded lowest weed presence in wheat crop. Combining the highest seeding rate $\left(200\right.$ seeds $\left.\mathrm{m}^{-2}\right)$, and the earliest time of weed removal (two-leaf stage of canola) led to a $41 \%$ yield increase, compared with the combination of the lowest seeding rate $\left(100\right.$ seeds $\left.\mathrm{m}^{-2}\right)$ and the latest time of weed removal (six-leaf stage of canola), with glufosinate applied at $500 \mathrm{~g}$ a.i. ha ${ }^{-1}$ (Harker et al., 2003). Higher seeding rate favors rice more than weeds and increases yield under weedy conditions (Phuong et al., 2005). Echinochloa cruss-galli and Leptochloa chinensis densities were reduced at higher rice seeding rates of $200 \mathrm{~kg} \mathrm{ha}^{-1}$ and POST EM herbicide application, when compared with 100 $\mathrm{kg} \mathrm{ha}^{-1}$ seeding rate with the same herbicides (Hiraoka et al., 1998). Similarly, according to Ahmed et al. (2014) weed biomass decreased significantly (by 55\%) when seeding rice rate increased from 20 to $100 \mathrm{~kg} \mathrm{ha}^{-1}$. Ridge sowing in combination with pendimethalin + prometryne applied at $875 \mathrm{~g}$ a.i. ha ${ }^{-1}$ was the best method in terms of controlling weeds, reducing dry weight of weeds, increasing monopodial and sympodial branches per plant, total number of bolls per plant, number of mature bolls per plant, seed cotton weight and seed cotton yield (Nadeem et al., 2013). When herbicide was not applied in lentil and seed rate was increased by 1.5 times, this resulted in a $70 \%$ weed control, compared with $90 \%$ when seeding rate was the same and herbicides were used (Boerboom and Young, 1995).

Changes in sowing date can strongly affect plant development and have noticeable effects on weed intensity, crop growth and yield, as well (Hay, 1986). Sowing dates can be manipulated to avoid the periods of greatest risk from weeds and hence increase the crop yield (Harper, 1999). Furthermore, high seeding rates improve the ability of crops to suppress weeds and can reduce yield loss under partially-weedy conditions (Guillermo et al., 2009). Also, crop competition for light can be further improved with the use of higher seeding rates.

\section{SYNERGY BETWEEN HERBICIDES AND ALTERATION IN POPULATION DENSITY AND ROW SPACING}

Crop competitiveness against weeds can be improved by using higher crop population densities. Use of higher planting densities can accelerate canopy closure, thus promoting interception of radiation by the crop canopy and hence weed suppression (Andrade et al., 2002; Mashingaidze, 2009). Furthermore, increased crop density increases the degree of "size-asymmetric competition", to the advantage of the crop, which almost always has an 
initial size advantage in competition with annual weeds (Weiner et al., 2001). Finally, increased crop density and uniformity can contribute to weed management in many crops, potentially reducing the need for herbicides or mechanical weed control (Marin and Weiner, 2014). Closer row spacing and higher plant populations per hectare are common practices for peanut, soybean and vegetable crops where, after introduction of herbicides, crop yields increased in snap beans (45\%), sweet corn (50\%), carrots (22-33\%) and broccoli (65\%) (Mack, 1969). In the study by Safdar et al. (2011), the $22.5 \mathrm{~cm}$ single row sowing in combination with chemical weed control proved to be the best option, regarding weed control $(87.23 \%)$, wheat grain yield (4073 $\mathrm{kg} \mathrm{ha}^{-1}$ ) and number of fertile tillers $\mathrm{m}^{-2}(509.5)$. The effect of narrow row spacing and interaction of herbicides on weeds and wheat grain yield was recorded by Ashrafi et al. (2009). Minimum number of weeds $\left(8 \mathrm{~m}^{-2}\right.$ grasses and $10 \mathrm{~m}^{-2}$ broadleaf $)$, as well as the highest grain yield $\left(5.35 \mathrm{t} \mathrm{ha}^{-1}\right)$ was recorded in $20 \mathrm{~cm}$ row spacing treated with 2,4-D butyl Ester $72 \mathrm{EC}+$ isoproturon 75 WP. Maize weed control by hoeing or herbicide treatments resulted in smaller weed biomass and greater maize yield in narrow-, when compared to wide-spacing maize (Hussein et al., 2008). Teasdale (1995) found that, when herbicide was applied at a standard rate, zero weeds emerged when row spacing was halved (from $76 \mathrm{~cm}$ to $38 \mathrm{~cm}$ ) and maize density doubled (from 58,000 to 109,000 plants ha-1), when compared with $3 \%$ weed cover at standard row spacing and planting density. Dalley et al. (2004) investigated the effects of glyphosate application timing coupled with reduced row spacing in glyphosate-resistant maize. When glyphosate was applied sequentially at five different weed growth stages over four seasons, the higher light interception by the maize canopy resulted in $60 \%$ less weed biomass, compared to wider rows. In the same study, a single application of glyphosate at the beginning of the season, coupled with halved row spacing, reduced weed biomass by $39 \%$ over four seasons. In a study by Teasdale (1995), the use of narrower rows and increased plant population by only $25 \%$ of the recommended herbicide rate showed no significant differences in weed control, when compared with the recommended herbicide rates, applied under conventional row spacing and maize population. Intra-row spacing of $15 \mathrm{~cm}$ and the use of pre-emergence application of metolachlor + prometryne at $1.6 \mathrm{~kg}$ a.i. $\mathrm{ha}^{-1}$, followed by one supplementary hoe-weeding at 6 WAS, controlled weeds effectively, with consequent high groundnut pod yield, when compared to those of two hoe-weeding (Ojelade et al., 2018). Adigun et al. (2016) cit. by Ojelade et al. (2018) also reported that intra-row spacing of $15 \mathrm{~cm}$ and application of probaben and butachlor at $2.0 \mathrm{~kg}$ a.i ha-1, followed by supplementary hoe weeding at 6 WAS. gave better weed control than either of the herbicides applied alone in groundnut. Higher than $90 \%$ control of Panicum dichotomiflorum, Eleusine indica, Digitaria sanguinalis, Amaranthus spp. and Ipomoea spp. was obtained in narrow-row cotton with glufosinate applied early POST and mid-POST EM to two- and six-leaf cotton, respectively (Wilson et al., 2007). Among soybean planting systems, narrow with high plant density soybeans in combination with PRE and POST EM herbicide programs reduced total weed biomass by $81-100 \%$, when compared to wide-row spacing with low soybean plant density (Koger et al., 2002). Shading by the soybean canopy in 10-in rows reduced the survival of late-emerging Setaria faberi and improved late-season control ratings to 84\% (Hartzler et al., 
1996). Ambrosia artemisiifolia and Chenopodium album control by all herbicide treatments was enhanced in narrow-, when compared to wide-row soybean 56 DAT as was Amaranthus retroflexus control by CGA-277476 treatment. POST EM herbicide treatments resulted in less weed biomass and greater soybean yield in narrow-, when compared to wide-row soybean (Nelson and Renner, 1998).

\section{SYNERGY BETWEEN HERBICIDES AND FERTILIZER APPLICATION}

Furthermore, the benefits of fertilization depend on weed control. The application of fertilizers causes more weeds to grow, if they are not controlled properly. By controlling the weed problem with herbicides, farmers will be more likely to use fertilizers for an even greater crop yield increase (Manda, 2011). The use of subnormal herbicide doses (50\%) and $\mathrm{N}$ fertilization may be useful in wheat production systems (conventional and no tillage systems) as a strategy to manage natural weed populations (Ashrafi et al., 2010). Soltani and Saeedipour (2015) revealed that effects of graminaceous herbicide, in combination with ammonical nitrogen on silty clay soil, resulted in a remarkable increase in grain yield of wheat crop. Najafi and Ghadiri (2012) reported that there is a synergy created by foramsulfuron $0.06 \mathrm{~kg}$ a.i. ha- ${ }^{-1}$ in the presence of nitrogen $50 \mathrm{~kg} \mathrm{ha}^{-1}$ to ensure good control of Convolvulus arvensis L., Amaranthus retroflexus L. and Physalis alkekengii L. in barley crop. Mesosulfuron-methyl plus iodosulfuron-methyl decreased weed dry matter by $86.2 \%$ with highest level on nitrogen (304 kg urea ha-1) when compared to the respective weedy check treatments (Sheibani and Ghadiri, 2012). The results of Sepahvand et al. (2014) show improved efficiency of nitrogen utilization by banding herbicide application. Grain yield, harvest index, seed rows per cob, seeds per row and cob weight were increased by weed control. In the application of foramsulfuron + hand weeding (HW) treatment corn grain yield was increased $126 \%$ in comparison with weedy control. Such results are a representation of the intense affects of weed competition with corn. The highest corn grain yield $\left(6758 \mathrm{~kg} \mathrm{ha}^{-1}\right)$ was related to the application banding of nitrogen fertilizer and foramsulfuron + once HW (Sepahvand et al., 2014). Similarly, in maize production, grain yield increases after the application of $3 \%$ urea as NPK (160-80-50), in combination with $1125 \mathrm{~g}$ a.i. ha ${ }^{-1}$ foramsulfuron applied POST EM, having reduced the density of three invasive species: Trianthema portulacastrum, Cyperus rotundus and Coronopus didymus (Nadeem et al., 2008). Maize grain yield gain and better control of Echinocloa crus-galli, Sorghum halepense, Cynodon dactylon, Digera muricata, Portulaca oleracea, Convolvulus arvensis and Cyperus rotundus was induced by atrazine $1 \mathrm{~kg}$ a.i. ha- ${ }^{-1}$ and $160 \mathrm{~kg} \mathrm{~N} \mathrm{ha}^{-1}$, compared to stomp 0.75 $\mathrm{kg}$ a.i. ha ${ }^{-1}$ subjected to the same conditions and 2.4 D-72 (ester) 0.80 a.i. $\mathrm{kg} \mathrm{ha}^{-1}$ applied in post-emergence or 25 days after sowing (Khan et al., 2012a). The lowest weed density (30.83 weeds $\left.\mathrm{m}^{-2}\right)$ and the lowest dry weed biomass $\left(6.80 \mathrm{~g} \mathrm{~m}^{-2}\right)$, as well as the greatest grain yield production $\left(1.5 \mathrm{t} \mathrm{ha}^{-1}\right)$ was recorded in plots treated with atrazine $38 \mathrm{SC}$, followed by the application of $160 \mathrm{~kg} \mathrm{ha}^{-1} \mathrm{~N}$ (Khan et al., 2012b). Applying the two herbicides alone at the recommended doses was good enough for controlling both types of weeds, broad and narrow 
leaved ones. However, using both of them in combination with different fertilizers (i.e., urea and diammonium phosphate) was much more effective (Abouziena, 2007). The presence of adjuvant MSO, especially with nitrogen fertilizer, AMN and UAN, improved the half rate (30 $\mathrm{g} \mathrm{ha}^{-1}$ ) nicosulfuron activity in the control of Chenopodium album, Viola arvensis, Polygonum convolvulus, Polygonum aviculare and particularly Echinochloa crus-galli in maize (Idziak and Woznica, 2013). Mesotrione + nicosulfuron in $50 \mathrm{~cm}$ row distance and standard urea application provided $96.65 \%$ control of weeds in maize (Simić et al., 2017). Increasing N application rate up to $150 \mathrm{~kg} \mathrm{ha}^{-1}$ caused significant improvement in grain rice yield when the weeds were well controlled either by pendimethalin + bispyribac $\mathrm{Na}$ or by pendimethalin + bispyribac $\mathrm{Na}+1 \mathrm{HW}$, respectively (Mahajan and Timsina, 2011). Increased application of $\mathrm{N}$ up to $90 \mathrm{~kg}$ $\mathrm{ha}^{-1}$, and complementary weed control by pre-transplant application of butachlor $(50 \% \mathrm{w} / \mathrm{v})$ or probaben (metolachlor $20 \% \mathrm{w} / \mathrm{v}+$ prometryn $20 \% \mathrm{w} / \mathrm{v}$ ) each at $2.0 \mathrm{~kg}$ a.i. ha ${ }^{-1}$, followed by supplementary hoe weeding at 6 weeks after transplanting (WAT), significantly reduced weed density by at least $15 \%$ and increased fruit yield of tomato by at least $32 \%$, compared to the use of pre-transplant herbicides alone, across both years of study (Adigun et al., 2018).

Nutrient level is often important for crop-weed competitive interactions (Lintell-Smith et al., 1992) and managing the application of fertilizers in both space and time can be a tool in managing weeds (Angonin et al., 1996; Liebman and Mohler 2001). Manipulation of crop fertilization is a promising cultural practice to reduce weed interference in crops (Di Tomaso, 1995; Evans et al., 2003). In conclusion, manipulation of certain agronomic practices for crop competition, such as sowing date, seeding rate, row and plant spacing and the application of fertilizers in synergy with herbicide applications, led to high levels of crop production, reductions in the abundance of agricultural weeds, optimal herbicide use and reduction of herbicide dependence, increase in net returns, and the adoption of more integrated weed management systems. Such a strategy also offers an environmentally friendly alternative to mechanical weed control, reducing traffic on the field, soil erosion, nutrient loss, labour, fuel consumption and $\mathrm{CO}_{2}$ emissions.

\section{REFERENCES}

Abouziena, H. F., El-Karmany, M. F., Singh, M., Sharma, S. D.: Effect of nitrogen rates and weed control treatments on maize yield and associated weeds in sandy soils. Weed Technology, 21 (4), 1049-1053, 2007.

Adigun, J. A., Daramolaa, O. S., Adeyemia, O. R., Olorunmaiyea, P. M., Osipitan, O. A.: Nitrogen and weed management in transplanted tomato in the Nigerianforest-savanna transition zone. Annals of Agrarian Science, 16 (3), 281-285, 2018.

Ahmed, S., Salim, M., Chauhan, B. S.: Effect of weed management and seed rate on crop growth under direct dry seeded rice systems in Bangladesh. PLoS ONE 9(7), e101919, 2014 https://doi.org/10.1371/journal. pone.0101919.

Akter, N., Amin, A. K. M. R., Haque, M. N., Masum, S. M.: Effect of sowing date and weed control method on the growth and yield of soybean. Poljoprivreda, 22, (1) 19-27, 2016.

Andrade, F. H., Calvinho, P., Cirilo, A., Barbieri, P.: Yield responses to narrow rows depend on increased radiation interception. Agronomy Journal, 94, 975-980, 2002. 
Angonin, C., Caussanel, J. P., Meynard, J. M.: Competition between winter wheat and Veronica hederifolia: influence of weed density and theamount and timing of nitrogen application. Weed Research, 36, 175-187, 1996.

Anonymous: Principles and practices of commercial farming. Published by Faculty of Agriculture and Home Economics, University of Manitoba, Winnipeg, MB, 1968.

Arslan, N., Zulfiqar, U., Ishfaq, M., Ahmad, M., Anwar, M., Ullah, A., Nazar, I., Iqbal, A., Anjum, M.: Weed Control practices and varying sowing dates effects on seed production of pearl millet (Pennisetum americanum L.) under semi-arid environment. American Journal of Plant Sciences, 9, 1974-1986, 2018.

Ashrafi, Z. Y., Sadeghi, S., Mashhadi, H. R.: Study of integrate methods chemical and cultural control of weeds to wheat (Triticum aestivum L.). Journal of Agricultural Science, 1 (2), 113-119, 2009.

Ashrafi, Z. Y., Alizade, H. M., Mashhadi, H. R., Sadeghi, S.: Study effect of tillage, herbicide and fertilizer rates on wheat (Triticum aestivum) and weed populations, in Iran. Bulgarian Journal of Agricultural Science, 16, 59-65, 2010.

Avery, A. A.: Saving the planet with pesticides. Biotechnology, and European Farm Reform, Proceedings Brighton Crop Protection Conference - Weeds, 1, 3-18, 1997.

Boerboom, C. M., Young, F. L.: Effect of post plant tillage and crop density on broad leafweed control in pea (Pisum sativum L.) and lentil (Lens culinaris). Weed Technology, 9, 99-106, 1995.

Chhokar, R. S., Sharma, R. K., Sharma, I.: Weed management strategies in wheat-A review. Journal of Wheat Research, 4 (2), 1-21, 2012.

Conley, S. P., Binning, L. K., Connell, T. R.: Effect of cultivar, row spacing, and weed management on weed biomass, potato yield, and net crop value. American Journal of Potato Research, 78, 31-37, 2001.

Cousens, R., Mortimer, M.: Dynamics of weed populations. Cambridge University Press, Cambridge, UK. 332 pp, 1995.

Dalley, C. D., Kells, J. J., Renner, K. A.: Effect of glyphosate application timing and row spacing on weed growth in corn (Zea mays) and Soybean (Glycine max).Weed Technology, 18, 177-182, 2004.

Darwent, A. L., Smith, J. H.: Delayed seeding for wild oat control in rapeseed in northwest Alberta. Canadian Journal of Plant Science, 65, 1101-1106, 1985.

Del Grosso, S. J., Mosier, A. R., Parton, W. J., Ojima, D. S.: DAYCENT model analysis of past and contemporary soil NO and net greenhouse gas flux for major crops in the USA. Soil and Tillage Research, 83, 9-24, 2005.

Di Tomaso, J. M.: Approaches for improving crop competitiveness through the manipulation of fertilization strategies. Weed Science, 43, 491-497, 1995.

Duary, B., Yaduraju, N. T.: Effect of sowing date, seed rate of wheat and different densities of little seed canary grass (Phalaris minor Retz.) on growth and productivity of wheat. Journal of Crop and Weed, 1 (1), 5-8, 2006.

Erfanifar, S., Bijanzad, A., Rauf, M., Behpori, A.: Evaluation in chemical, mechanical and integrated control methods for weeds of corn in Darab area. Research Reconstruction, 76, 109-118, 2008.

Evans, S. P., Knezevic, S. Z., Lindquist, J. L., Shapiro, C. A., Blankenship, E. E.: Nitrogen application influences the critical period for weed control in corn. Weed Science, 51 (3), 408-417, 2003.

Filizadeh, Y., Rezazadeh, A., Younessi, Z.: Effects of crop rotation and tillage depth on weed competition and yield of rice in the paddy fields of Northern Iran. Journal of Agricultural Science and Technology, 9, 99-105, 2007.

Guillermo, D. A., Pedersen, P., Hartzler, R. G.: Soybean seeding rate effects on weed management. Weed Technology, 23, 17-22, 2009.

Gürsoy, S. Özaslan, C., Urğun, M., Kolay, B., Koç, M.: The effect of sowing time, tillage system and herbicides on weed species density, weed biomass and yield of lentil within a lentil-wheat sequence. Agriculture \& Forestry, 60 (3), 73-85, 2014.

Hamouz, K., Lachman, J., Dvořák, P., Pivec, V.: The effect of ecological growing on the potatoes yield and quality. Plant Soil and Environment, 51, 397-402, 2005.

Harker, K. N., Clayton, G. W., Blackshaw, R. E., O’Donovan, J. T., Stevenson, F. C.: Seeding rate, herbicide timing and competitive hybrids contribute to integrated weed management in canola (Brassica napus). Canadian Journal of Plant Sciences, 83, 433-440, 2003. 
Harper, F.: Principles of arable crop production. Blackwell Science, London, UK. 1999.

Hartzler, R. G., Benson, G. O., Shannon, D.: Effect of row spacing and seeding rates on soybean yields and weed management programs (1996). Leopold Center Completed Grant Reports. 81, 1996. http://lib.dr.iastate. edu/leopold_grantreports/81

Hassan, G., Marwat, K. B.: Integrated weed management in agricultural crops. In Proceedings of National Workshop on Technologies for Sustainable Agriculture, Faisalabad. 24-26 September 2001. Nuclear Institute for Agriculture and Biology (NIAB), Faisalabad, Pakistan, 2001.

Hay, R. K. M.: Sowing date and the relationships between plant and apex development in winter cereals. Field Crops Research, 14, 321-337, 1986.

Hiraoka, H., Tan, P. S., Khuong, T. Q., Huan, N. T.: On seeding rate in wet seeded culture in alluvial soil of the Mekong delta. Paper presented at the workshop on rice technology in Central Vietnam, 20-21 August, 1998, Qui Nhon, Vietnam, 1998.

Hussein, F., Abouziena, I. M., El-Metwally, El-Desoki, E. R.: Effect of plant spacing and weed control treatments on maize yield and associated weeds in sandy soils. American-Eurasian Journal of Agricultural \& Environmental Sciences, 4 (1), 9-17, 2008.

Idziak, R., Woznica, Z.: Effect of nitrogen fertilizers and oil adjuvants on nicosulfuron efficacy. Turkish Journal of Field Crops, 18 (2), 174-178, 2013.

Iqbal, S.: Screening of different herbicides for controlling weeds in wheat crop. M.Sc. (Hons.) Thesis. Gomal University, Faculty of Agriculture, Dera Ismail Khan, Pakistan, 1994.

Jhala, A. J., Shah, S. C., Paresh, H. R., Bhat, H.: Integrated effect of seed rates and weed management treatments in wheat (Triticum aestivum L.). Research Journal of Agriculture and Biological Sciences, 4 (6), 704-711, 2008.

Khan, N., Khan, N. W., Khan, I. A.: Integration of nitrogen fertilizer and herbicides for efficient weed management in maize (Zea mays) crop. Sarhad Journal of Agriculture, 28 (3), 457-463, 2012a.

Khan, N., Khan, N. W. ,Khan, S. A., Khan, M. A., Marwat, K. B.: Combined effect of nitrogen fertilizers and herbicides upon maize production in Peshawar. The Journal of Animal and Plant Sciences, 22, 12-17, 2012b.

Kirschbaum, M. U. F.: The temperature dependence of soil organic matter decomposition, and the effect of global warming on soil organic C storage. Soil Biology \& Biochemistry, 27, 753-760, 1995.

Klein, R. N., Martin, A. R., Lyon, D. J.: Annual broadleaf weed control in winter wheat. NebGuide G1241, University of Nebraska-Lincoln Extension, Institute of Agriculture and Natural Resources, Lincoln, Nebraska, USA, 2006.

Koger, C. H., Reddy, K. N., Shaw, D. R.: Effects of rye cover crop residue and herbicides on weed control in narrow and wide row soybean planting systems Weed Biology and Management, 2, 216-224, 2002.

Kucharik, C. J.: A multi-decadal trend of earlier corn planting in the central USA. Agronomy Journal, 98, 1544-1550, 2006.

Liebman, M., Mohler, C. L.: Weeds and the soil environment. In: M. Liebman, C.L. Mohler, CP. Staver (Eds.), Ecological Management of Agricultural Weeds. Cambridge, UK: Cambridge University Press, pp. 210-268, 2001.

Lintell-Smith, G., Baylis, J. M., Watkinson, A. R.: The effects of reduced nitrogen and weed competition on the yield of winter wheat. Aspects of Applied Biology, 30, 367-372, 1992.

Mack, H. J.: Plant populations of vegetable crops as affected by weed control. $21^{\text {th }}$ Annual California Weed Conference, California, SAD, 1969.

Mahajan, G., Timsina, J.: Effect of nitrogen rates and weed control methods on weeds abundance and yield of direct-seeded rice. Archives of Agronomy and Soil Science, 57, (3), 239-250, 2011.

Manda, P.: Evaluation report on the impact of spray service technology uptake on small-scale farmer livelihoods in Zambia. CARE, Zambia, 2011.

Marin, C., Weiner, J.: Effects of density and sowing pattern on weed suppression and grain yield in three varieties of maize under high weed pressure. Weed Research, 54, 467-474, 2014. 
Marwat, K. B., Khan, M. A., Hashim, S., Nawab, K., Khattak., A. M.: Integrated weed management in wheat. Pakistan Journal of Botany, 43 (1), 625-633, 2011.

Mashingaidze, A. B., van der Werf, W., Lotz, L. A. P., Chipomho, J., Kropff, M. J.: Narrow rows reduce biomass and seed production of weeds and increase maize yield. Annals of Applied Biology, 155, 207-218, 2009.

Mubeen, K., Nadeem, M. A., Tanveer, A., Jhala, A. J.: Effects of seeding time and weed control methods in direct seeded rice (Oryza sativa L.). The Journal of Animal \& Plant Sciences, 24 (2), 534-542, 2014.

Munir, A., Turk, A. R., Tawaha, M.: Effect of sowing rates and weed control methods on winter wheat under mediterranean environment. Journal of Agronomy, 1, 25-27, 2002.

Nadeem, M. A., Idrees, M., Ayub, M., Tanveer, A., Mubeen, K.: Effect of different weed control practices and sowing methods on weeds and yield of cotton. Pakistan Journal of Botany, 45 (4), 1321-1328, 2013.

Nadeem, M. A., Ahmad, R., Khalid, M., Naveed, M., Tanveer, A., Ahmad, J. N.: Growth and yield response of autumn planted maize (Zea mays L.) and its weeds to reduced doses of herbicide application in combination with urea. Pakistan Journal of Botany, 40, 667-676, 2008.

Najafi, B., Ghadiri, H.: Weed control and grain yield response to nitrogen management and herbicides. Journal of Biological and Environmental Sciences, 6, 39-47, 2012.

Nelson, K. A., Renner, K. A.: Weed control in wide- and narrow-row soybean (Glycine max) with imazamox, imazethapyr, and CGA-277476 plus quizalofop. Weed Technology, 12 (1), 137-144, 1998.

Ojelade, O. B., Lagoke, S. T., Adigun, J. A., Babalola, O. A., Daramola, O. S., Osipitan, O. A.: Intra-row spacing and weed control influence growth and yield of groundnut (Arachis hypogea L.). Advances in Agricultural Science, 6 (4), 01-11, 2018.

Phuong, L. T., Denich, M., Vlek, P. L. G., Balasubramanian, V.: Suppressing weeds in direct seeded lowland rice: effects of methods and rates of seeding. Journal of Agronomy and Crop Science, 191, 185-194, 2005.

Prakash, A., Sharma, K. C., Mishra, R. D.: Control of Phalaris minor and wild oats in wheat by cultural and chemical methods. Indian Journal of Agronomy, 31, 411-413, 1986.

Prishchepa, I. A.: The efficacy of decreased herbicide rates applied with major fertilizers to barley and winter wheat crops. Agrokhimiya, 7, 71-80, 1999.

Safdar, M. E., Asif, M., Ali, A., Aziz, A., Yasi, M., Aziz, M., Afzal, M., Ali, A.: Comparative efficacy of different weed management strategies in wheat. Chilean Journal of Agricultural Research, 71 (2), 195-204, 2011.

Saini, J. P., Angiras, N. N.: Efficacy of isoproturon in relation to irrigation and top dressing of $\mathrm{N}$ in wheat. Indian Journal of Weed Science, 30, 113-115, 1998.

Schoofs, A., Entz, M. H., Van Acker, R. C., Thiessen Martens, J. R., Derksen, D. A.: Agronomic performance of pesticide free production under two crop rotations. Ren. Agriculture and Food Systems, 20 (2), 91-100, 2005.

Sepahvand, P., Sajedi, N. ,Mousavi, S. K., Ghiasvand, M.: Effects of nitrogen application method and weed control on corn yield and yield components. Pakistan Journal of Biological Sciences, 17, 497-503, 2014.

Sheibani, S., Ghadiri, H.: Integration effects of split nitrogen fertilization and herbicide application on weed management and wheat yield. Journal of Agricultural Sciences and Technology, 14, 77-86, 2012.

Shrestha, A., Hanson, B. D., Fidelibus, M. W., Alcorta, M.: Growth, phenology, and intraspecific competition between glyphosate-resistant and glyphosate-susceptible horseweeds (Conyza canadensis) in the San Joaquin valley of California. Weed Science, 58, 147-153, 2010.

Simić, M., Brankov, M., Dragičević, V.: Effects of nitrogen form, row spacing and herbicide application on weed control and maize biomass production. Herbologia, 16 (2), 35-48, 2017.

Soltani, F., Saeedipour, S.: Efficacy evaluation of some herbicides and different nitrogen levels for weed management and yield attributes in wheat. Journal Wallis, 31, 39-43, 2015.

Sosnoskie, L. M., Culpepper, A. S., York, A. C., Beam, J. B., MacRae, A. W.: Sequential applications for mesosulfuron and nitrogen needed in wheat. Weed Technology, 23, 404-407, 2009.

Teasdale, J. R.: Influence of narrow row/high population corn (Zea mays) on weed control and light transmittance. Weed Technology, 9, 113-118, 1995. 
Thierfelder, C., Wall, P. C.: Effects of conservation agriculture techniques on infiltration and soil water content in Zambia and Zimbabwe. Soil and Tillage Research, 105, 217-227, 2009.

Wall, P. C.: Tailoring conservation agriculture to the needs of small farmers in developing countries: An analysis of issues. Journal of Crop Improvement, 19, 137-155, 2007.

Warren, G. F.: Spectacular increases in crop yields in the United States in the twentieth century. Weed Technology, 12, 752-760, 1998.

Weiner, J., Griepentrogh, W., Kristensen, L.: Suppression of weeds by spring wheat (Triticum aestivum) increases with crop density and spatial uniformity. Journal of Applied Ecology, 38, 784-790, 2001.

Weller, S. C., Culbreath, A. K. Gianessi, L., Godfrey, L. D.: The contributions of pesticides to pest management in meeting the global need for food production by 2050. CAST Issue Paper 55 Task Force Members, 2014.

Wilson, Jr. D. G., York, A. C., Jordan, D. L.: Effect of row spacing on weed management in glufosinate-resistant cotton. Weed Technology, 21, 489-495, 2007.

Woźniak, A., Soroka, M.: Structure of weed communities occurring in crop rotation and monoculture of cereals. International Journal of Plant Production, 9 (3), 487-506, 2015.

\section{Sinergizam kompeticije, agrotehničkih mera i primene herbicida za efikasno suzbijanje korova u biljnoj proizvodnji}

REZIME

Zajednička primena herbicida i agrotehničkih mera za jačanje kompetitivne spsobnosti useva, pored ostalog, uključuje pravovremene rokove setve, setvenu normu i primenu đubriva koji potencijalno mogu umanjiti zakorovljenost useva i optimizirati primenu herbicida. Datum setve i primjena herbicida imaju značajnu ulogu za rast, razvoj i prinos mnogih useva, kao i smanjenje brojnosti i biomase korova. Manje međuredno rastojanje može doprineti lakšem i efikasnijem hemijskom suzbijanju korova iz razloga izraženijeg kompetitivnog pritiska useva u odnosu na veći međuredni razmak. Pored toga, brži rast i razvoj useva sa manjim međurednim razmakom smanjuje kasniju pojavu korova i omogućava raniju primenu POST EM herbicida, čime se obezbežuje čist usev kao preduslov za visok prinos. Takođe, adekvano đubrenje pozitivno utiče na brži rast i razvoj useva a time i kompetitivnu snagu u odnosu na korove. Dakle, dobrim rokovima i gustinom setve, đubrenjem i primenom herbicida jača se kometitvna prednost useva u odnosu na korove.

Ključne reči: agrotehničke mere, herbicidi, đubrivo, korovi. 